\title{
9. MINERALS OF THE CLAY FRACTION IN PLIOCENE-QUATERNARY SEDIMENTS OF THE EAST EQUATORIAL PACIFIC
}

\author{
M. A. Rateev, P. P. Timofeev, and N. V. Rengarten, Geological Institute of the USSR Academy of Sciences, \\ Moscow, USSR
}

\section{INTRODUCTION}

This is a study of clay minerals in oceanic sediments penetrated during drilling on Deep Sea Drilling Project Leg 54. In this paper we elucidate the clay mineral distribution in several holes and present mineralogical descriptions of a green $\mathrm{K}, \mathrm{Fe}$-smectite from the mounds geothermal field of the Galapagos Spreading Center (GSC) and an Fe-montmorillonite from Pliocene-Quaternary sediments of the East Pacific Rise (EPR) near the Siqueiros fracture zone.

We examined over 90 samples collected by Yu. I. Dmitriev aboard the Glomar Challenger, using X-ray diffraction analysis. The samples were from Hole 424B in the geothermal field, about $22 \mathrm{~km}$ south of the GSC, from Hole 425 about $65 \mathrm{~km}$ north of the GSC, and from Sites 419, 420, 422, 423, and 428 near the EPR (Figure 1). The analyses were carried out on the $<10=\mu \mathrm{m}$ and on the $<1=\mu \mathrm{m}$ fractions to determine the clay mineralogy.

\section{METHODS}

In preparing the samples for analysis, amorphous substances were removed by the method of Hashimoto and Jackson (1960). The samples were treated with 10 per cent $\mathrm{HCl}$, and heated at $80^{\circ} \mathrm{C}$ for an hour to determine the stability and iron type of smectites. Heating was continued until all the Fe-montmorillonite had decomposed but common (aluminous) montmorillonite was still preserved. X-ray diffraction analyses were ef-

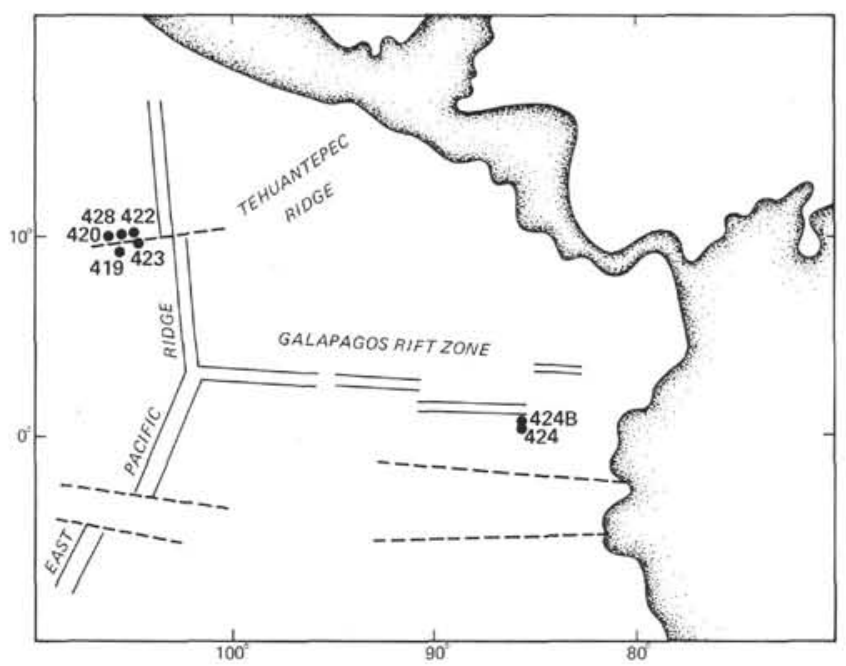

Figure 1. Location map of Leg 54 sites. fected, using a DRON-1 (USSR) diffractometer (radiation $=\mathrm{CuK}_{\alpha}$, at $35 \mathrm{~kW}$ and $20 \mathrm{~mA}$ ). The scanning rate was $2^{\circ} /$ minute. Diffractograms were obtained on untreated (i.e., air-dry) samples, on glycolated samples, and samples that were heated to $550^{\circ} \mathrm{C}$. A third group of samples was run before and after removal of amorphous substances, and then after further treatment with $\mathrm{HCl}$. Identification of clay minerals, including mixedlayer structures, was carried out following Brindley (1951), MacEwan (1955), Reynolds (1968), Drits and Sakharov (1976), and Gradusov (1976).

\section{IDENTIFICATION AND STRUCTURAL FEATURES OF THE CLAY MINERALS}

Utilizing X-ray diffraction analysis, differential thermal analysis (DTA), infrared spectrometry, and electron microscopy, we have established that the clay fraction of Pliocene-Quaternary sediments of Leg 54 consists of minerals of the smectite group in three structural modifications-Fe-montmorillonite, green $\mathrm{K}, \mathrm{Fe}$-smectite, and common aluminous montmorillonite, with admixtures of illite, kaolinite, chlorite, and a vermiculitelike material.

\section{Fe-Montmorillonite}

In recent years an unstable ferruginous variety of montmorillonite has been distinguished in many oceanic sediments and in sediments from rift zones. Bischoff (1972, 1974) described a highly ferruginous smectite from the zone of thermal ore formation in the Red Sea in 1972 as a nontronite, and in 1974 as Fe-montmorillonite. The latter is characterized by not only a high $\mathrm{Fe}_{2} \mathrm{O}_{3}$ content (up to $25 \%$ ) but also a high $\mathrm{FeO}$ content $(>11 \%)$.

Aoki et al. (1974) described Fe-montmorillonite from the northeastern Pacific. Kossovskaya et al. (1975) showed clearly the relationship of Fe-montmorillonite to pyroclastic material of basaltic composition and its authigenic nature after studying Atlantic samples obtained during DSDP Leg 2. Butuzova et al. (1977) distinguished three genetic types of smectites from the clay fraction of red, deep-sea clays sampled throughout a transpacific profile (from Japan to Mexico): common detrital, stable (aluminous) montmorillonite, authigenic diagenetic montmorillonite formed through decomposition of volcanogenic material, and "synthetic" authigenic ferrimontmorillonite (from thermal solutions).

Among Leg 54 samples we also distinguish three types of smectites. Of these, Fe-montmorillonite is the major constituent of the clay fraction of Pliocene- 
Quaternary sediments of the EPR penetrated at Holes 420,422 , and 423 . It has strong peaks at 14.7 to $15.2 \AA$ in an untreated specimen (17.0 $\AA$ after glycolation, and 9.98 to $10.0 \AA$ after heating at $550^{\circ} \mathrm{C}$ ) which disappear after heating at $80^{\circ} \mathrm{C}$ in 10 per cent $\mathrm{HCl}$ for one hour (Figure 2). This instability of Fe-montmorillonite after treatment with $\mathrm{HCl}$ marks it as different from common montmorillonite. It has higher $\mathrm{Fe}_{2} \mathrm{O}_{3}$ contents (from 9.8 to $14.7 \%$ ), lower $\mathrm{FeO}$ (from 0.45 to $1.31 \%$ ) and $\mathrm{K}_{2} \mathrm{O}$ contents (from 1.08 to $2.25 \%$ ), and variable $\mathrm{Al}_{2} \mathrm{O}_{3}$ contents (from 6.9 to $12.9 \%$ ) (Table 1).

Its structural formula in the case of Sample 420-4-3 $(59-61 \mathrm{~cm})$ is: $\left[\mathrm{Si}_{3.90} \cdot \mathrm{Al}_{0.10}\right]\left[\mathrm{Al}_{0.98} \mathrm{Fe}_{0.53}^{+3} \mathrm{Fe}_{0.07}^{+2} \mathrm{Mg}_{0.28}^{+2}\right]$ $\mathrm{K}_{0.20} \mathrm{Na}_{0.20}(\mathrm{OH})_{2} \cdot 1.32 \mathrm{H}_{2} \mathrm{O}$.

Highly charged Fe-montmorillonite from Hole 420 is very similar to $\mathrm{Fe}$-montmorillonite described by Aoki et al. (1974). According to the latter's data, Fe-montmorillonite contains from 14 to 18 per cent $\mathrm{Fe}_{2} \mathrm{O}_{3}$ fixed in the octahedral layer, the $\mathrm{Al}_{2} \mathrm{O}_{3}$ content in this layer ranging from 3.25 to 8.58 per cent.

\section{$\mathbf{K}, \mathbf{F e}-$ Smectite}

A green celadonite-like mineral from the Galapagos geothermal field (Hole 424B) is not a chlorite-smectitic mineral, but $\mathrm{K}, \mathrm{Fe}$-smectite in which some interlayer sites are taken by K cations (Timofeev, et al., 1979). $\mathrm{X}$-ray diffractograms of untreated samples of this mineral show the 001 peak at $11.2-11.9 \AA$, shifting to 17.8 $\AA-18.2 \AA$ after glycolation, and to $9.97-10.0 \AA$ after heating at $550^{\circ} \mathrm{C}$. An additional saturation, with not only glycerine but also $\mathrm{KOH}$, does not cause expansion of the layers, and preserves the basal $11.06 \AA$ peak. This testifies to $\mathrm{K}$ fixation of interlayer spaces in smectite (Figure 2), fixes the 060 spacing at $1.5095 \AA$, and affirms a dioctahedral type of structure. Parameter " $b$ " $=9.057$ is close to that of nontronite. Closeness to the nontronite type of minerals was confirmed by the structural formula of $\mathrm{K}, \mathrm{Fe}$-smectite from Sample 424B2-3 (110-112 cm) from the GSC: $\left[\mathrm{Si}_{3.85} \mathrm{Al}_{0.15}\right]\left[\mathrm{Al}_{0.60}\right.$ $\left.\mathrm{Fe}_{1.80}^{+3} \mathrm{Fe}_{0.08}^{+2} \mathrm{Mg}_{0.34}^{+2}\right] \mathrm{Ca}_{0.04} \mathrm{~K}_{0.29} \mathrm{Na}_{0.02}(\mathrm{OH})_{2} \cdot 1.8 \mathrm{H}_{2} \mathrm{O}$.

This structural formula permits us to classify the authigenic $\mathrm{K}, \mathrm{Fe}$-smectite as having a hydrothermal genesis within a group of tetrasiliceous nontronites $\mathrm{Bu}$ tuzova et al., 1979). This K,Fe-smectite can be regarded as a mixed-layer mineral in which typically montmorillonitic spaces filled with hydroxyl ions alternate with spaces filled with potassium. This represents an initial degree of glauconitization, or celadonitization, if hydrothermal solutions take part in the processes of clay formation (as in Hole 424B). However, at subsequent, more intense stages of glauconitization and celadonitization, smectitic zones will alternate with ferruginous and potassic glauconite-like mica, in variable proportions as evidenced by changes of chemical composition, crystal-chemical features of the mineral, and variations in color (from yellow-green to dark green).

The interpretation that $\mathrm{K}, \mathrm{Fe}$-smectites from the $\mathrm{Ga}$ lapagos geothermal field of Hole 424B represent the initial stages of celadonization, is also confirmed by chemical analysis data. The $<1=\mu \mathrm{m}$ fraction, separated from green hydrothermal oozes of Hole 424B without any chemical treatment, has a high $\mathrm{Fe}_{2} \mathrm{O}_{3}$ content (from 27.6 to 30.9 per cent; Table 2) low $\mathrm{Al}_{2} \mathrm{O}_{3}$ contents (from 1.5 to $1.8 \%$ ), and somewhat higher $\mathrm{K}_{2} \mathrm{O}$ contents (from 2.1 to $3.2 \%$ ). The $\mathrm{SiO}_{2}$ content (about $48 \%$ ) approximates typical smectite minerals. The treatment of Femontmorillonite with lithium at $250^{\circ} \mathrm{C}$, after the method of Green-Kelly (1953), followed by glycolation, results in shifting of the $d / 001$ peak to $10 \AA$ thus testifying to the absence of beidelitic layers in its structure. Similar treatment of hydrothermal K,Fe-montmorillonite with chlorous lithium results in the appearance (besides the $10 \AA$ peak) of an expanded phase with $d / n$ $=17.6 \AA$ of the nontronitic type; this agrees well with a higher $\mathrm{Fe}_{2} \mathrm{O}_{3}$ content. The curves of differential thermal analysis (Figure 3 ) of $\mathrm{Fe}$ - and $\mathrm{K}, \mathrm{Fe}$-smectites are rather similar. They display a strong endothermal peak at $120-130^{\circ} \mathrm{C}$, a weak endothermal peak at $510-540^{\circ} \mathrm{C}$, and a scarcely noticeable exothermal peak at $800-830^{\circ} \mathrm{C}$. These curves are most similar to those of nontronites. Infrared spectra of authigenic K, Fe-smectites (Figure 4) also show a number of absorption peaks peculiar to nontronites, namely 3560,815 , and $680 \mathrm{~cm}^{-1}$.

Both $\mathrm{Fe}$ - and $\mathrm{K}, \mathrm{Fe}$-montmorillonite have the same smectite structure in which $\mathrm{Fe}^{+2}$ and $\mathrm{Fe}^{+3}$ replace $\mathrm{Al}$ atoms in the octahedral layer. Therefore, we can see the ratios of atomic $\mathrm{K}, \mathrm{Fe}$, and $\mathrm{Al}$ as a modulus $[(\mathrm{Fe}+\mathrm{K})$ / $\mathrm{Al}$ ] of the extent of replacement of $\mathrm{Al}$ by $\mathrm{Fe}$ in the octahedral layer and $\mathrm{K}^{+}$in interlayer species (Figure 5). The figure shows that according to this modulus, Fe-montmorillonites from Hole 420 and those studied by authors in Japan, as well as K, Fe-smectites of the Galapagos geothermal field (Hole 424B), lie on one line. Because the available chemical data are sparse, they are indicated by separate fields, but the modulus of celadonite-smectitic, mixed-layer minerals (Rateev et al., 1974) in hydrothermally altered Caucasus trachyandesites of Santonian age fills the gap between them. This bespeaks a similar transition mechanism of Fe-montmorillonite into $\mathrm{K}, \mathrm{Fe}$-montmorillonite of the glauconite-like (or celadonite-like) type for marine deposits as well as oceanic sediments.

\section{Other Clay Minerals}

The properties and parameters of common montmorillonite - that is, the dioctahedral aluminous varietyare well known and do not require special explanation. It is noteworthy that montmorillonitic minerals are rather widely distributed in samples of Leg 54 , being of volcanogenic or detrital origin, and characterized by a rather high dispersion of the particles. As a result, the $d / 001$ peak frequently is as high as 18 to $19 \AA$. Distinguishing these minerals from strongly expanded mixedlayer, montmorillonite-illitic (M-i) minerals is difficult (Reynolds, 1968; Drits and Sakharov, 1976). Although strongly expanded mixed-layer minerals are present here as a separate structural phase, we have not singled them out because they are difficult to recognize.

Vermiculites are characterized by a basal peak with $d / n=14.7 \AA$ which does not vary after saturation with glycerine, and by a peak of $10.2 \AA$ after heating at $550^{\circ} \mathrm{C}$. The mineral is not widely distributed in sedi- 


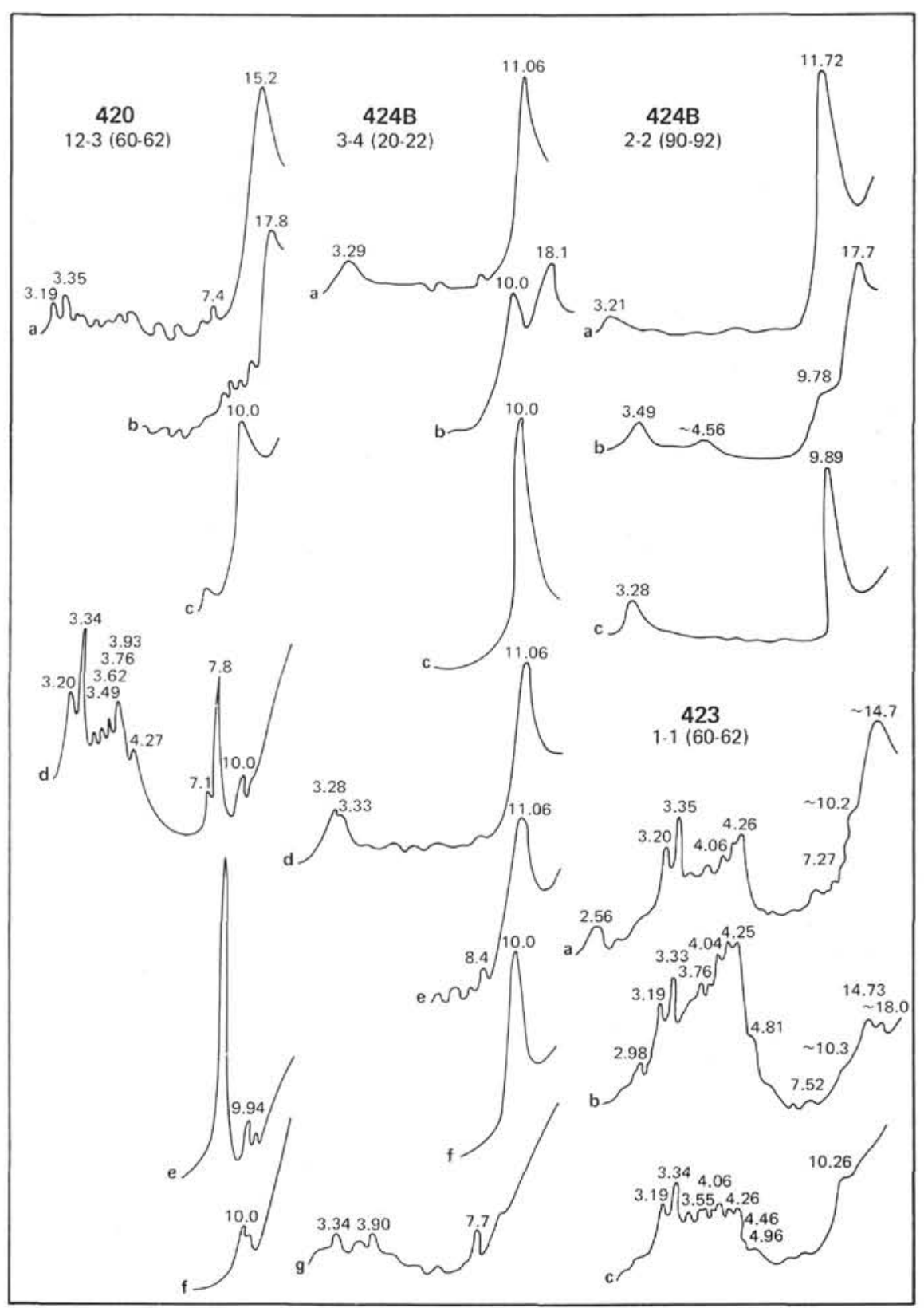

Figure 2. X-ray diffractograms of four clay minerals: $\mathrm{Fe}$-montmorillonite from Sample 420-12-3, 60-62 cm, fraction $<10 \mu \mathrm{m}$ after treatment by the Hashimoto and Jackson method. $a=$ air-dry, $b=$ saturated with glycerine, $c=$ heated at $550^{\circ} \mathrm{C}$, treated with 10 per cent $\mathrm{HCl}, d=$ airdry, $e=$ treated with glycerine, $f=$ heated. $K$, Fe-montmorillonites from Sample 424B-3-4, 20-22 cm, fraction <1 $\mu$ m, untreated samples: a $=$ air-dry, $b=$ subsequently treated with glycerine, $c=$ heated. Treated with $\mathrm{KOH}$ : $d=$ air-dry, $e=$ subsequently treated with glycerine, $f=$ heated, $g=$ subsequently treated with 10 per cent $\mathrm{HCl}$. Sample $424 \mathrm{~B}$ $-2-2,90-92 \mathrm{~cm}$, fraction $<1 \mu \mathrm{m}$, untreated sample. $a=$ air-dry, $b=$ subsequently treated with glycerine, $c=$ heated. Vermiculite-like mineral from Sample 423-1-1, 60-62 cm, untreated sample, fraction $<10 \mu \mathrm{m}$. a $=$ air-dry, $b=$ subsequently treated with glycerine, $c=$ heated . 
TABLE 1

Chemical Compositions of Fe-Montmorillonite Samples (wt. \%)

\begin{tabular}{|c|c|c|c|c|c|c|}
\hline \multirow{2}{*}{$\begin{array}{l}\text { Major } \\
\text { Oxides }\end{array}$} & \multicolumn{4}{|c|}{$\begin{array}{c}\text { From Pliocene-Quaternary Sediments, } \\
\text { OCP Ridge, Hole } 420 \text {, Fraction }<10 \mu \mathrm{m} \\
\text { Sample (interval in cm) }\end{array}$} & \multicolumn{2}{|c|}{$\begin{array}{c}\text { From OCP Ridge } \\
\text { region, Fraction } \\
<2 \mu \mathrm{m} \\
\text { (after Aoki et al., } \\
1974 \text { ) } \\
\text { Sample Station }\end{array}$} \\
\hline & $13-5,56-61$ & $4-3,59-61$ & $10-5,60-62$ & $8-2,59-61$ & $9 \mathrm{et}$ & 9Dt \\
\hline $\mathrm{SiO}_{2}$ & 51.43 & 54.53 & 53.07 & 58.74 & 52.12 & 52.28 \\
\hline & & 0.5 & & 0.3 & 1.14 & 0.93 \\
\hline $\mathrm{Al}_{2} \mathrm{O}_{3}$ & 10.48 & 12.90 & 8.88 & 6.86 & 8.33 & 7.08 \\
\hline $\mathrm{Fe}_{2} \mathrm{O}_{3}$ & 14.73 & 10.00 & 13.12 & 13.54 & 14.67 & 14.58 \\
\hline & & 1.31 & 0.70 & 0.32 & 0.3 & 0.21 \\
\hline $\mathrm{CaO}$ & 0.59 & 1.69 & 1.18 & 1.29 & 0.39 & 0.48 \\
\hline $\mathrm{MgO}$ & 3.74 & 2.65 & 2.95 & 2,20 & 4.14 & 4.74 \\
\hline $\mathrm{Na}_{2} \mathrm{O}$ & 0.77 & 1.38 & 0.95 & 0.70 & 1.30 & 1.20 \\
\hline $\mathrm{K}_{2} \mathrm{C}$ & 2.25 & 2.16 & 1.76 & 1.08 & 0.62 & 0.70 \\
\hline $\mathrm{H}_{2} \mathrm{O}^{+}$ & 6.75 & 7.24 & 9.69 & 7.09 & 6.44 & 6.78 \\
\hline $\mathrm{H}_{2}^{-} \mathrm{O}^{-}$ & 8.49 & 5.59 & 7.17 & 7.88 & 10.54 & 11.02 \\
\hline Total & 100.00 & 100.00 & 100.00 & 100.00 & 100.00 & 100.00 \\
\hline
\end{tabular}

Note: Coring station (Aoki et al., 1974), $17^{\circ}, 06^{\prime} \mathrm{N}, 146^{\circ} \mathrm{W}$; water depth, 4950 meters. Sample $9 \mathrm{ct}$, depth in the core $290-310 \mathrm{~cm}$; $9 \mathrm{Dt}$, interval $340-360$ $\mathrm{cm}$.

ments penetrated by Leg 54 holes. It is best diagnosed in the upper part of the section of Hole 423 in the Colosphaera tuberosa Zone of the northeastern slope of the EPR.

Chlorite occurs everywhere as a negligible admixture and is represented by a common trioctahedra ferruginous-magnesian variety.

Illite (hydromica) is of the dioctahedral sericitic type, sometimes with a small number of expanded packets.

Kaolinite occurs as a small detrital admixture everywhere, and is determined by standard peaks $d / 001=7.1$ $\AA$ and $d / 002=3.57 \AA$ which disappear after heating at $550^{\circ} \mathrm{C}$ and are preserved after treatment with $\mathrm{HCl}$.

\section{STRATIGRAPHIC AND SPATIAL DISTRIBUTION OF CLAY MINERALS IN LITHOLOGIC SECTIONS}

The vertical distribution of clay minerals in sections cored on Leg 54 is uniform and constant. Most likely this is related to stability of the nature of sedimentation in the eastern equatorial Pacific during a short period from Pliocene to the end of the Pleistocene. In fact, we observe only tendencies toward subtle changes in the total mineralogical composition of the clay fraction (such as the appearance of admixtures of other minerals) from relatively large litholo-stratigraphic units, the main complex being preserved (Figure 6). Different associations of clay minerals are more appreciable for different regions, as for instance between the Galapagos Island Rise (Hole 424B) and the southwestern slope of the EPR (Hole 420).

The following stratigraphic distribution of clay minerals in the three areas drilled during Leg 54 is given from the base of sections upwards.

\section{EPR (southwestern slope of the OCP Ridge)}

\section{Hole 420}

This hole is located 201 kilometers west of the axial zone of the EPR; the thickness of the sedimentary cover penetrated is 118.5 meters. Basalts underlying the sediments in Hole 420 were drilled to a depth of 28.7 meters. The oldest sediments, dated by means of radiolarians, are of late Pliocene age. The age of the basement estimated through magnetic anomalies is $3.37 \mathrm{~m} . \mathrm{y}$. The section is composed mostly of foraminifer-nannofossil oozes alternating in the uppermost part of the section with brown calcareous oozes. The clay mineral associations in Hole 420 are stable, varying only slightly up section.

Sediments of the radiolarian Pterocanium prismatium Zone (Sections 13-6 and 11-1) consist of clayey oozes with numerous siliceous organisms (radiolarians, sponge spicules, and small diatoms) with a constant admixture of acidic volcanic ash, relics of basic volcanic glass, and globules of authigenic Fe-montmorillonite. The clay fraction of the interval is characterized by abundant authigenic iron-rich, unstable-variety $\mathrm{Fe}$ montmorillonite, a small admixture of detrital minerals, illite, and, less abundantly, kaolinite.

The overlying lower Pleistocene series (the Anthocyrtidium angulare Zone) is represented by biogenic carbonate-siliceous oozes, including Ethmodiscus nannofossil oozes alternating with radiolarians in the upper part, and a small admixture of acid volcanic glass that decreases up the section.

Besides Fe-montmorillonite, the clay fraction of the entire interval of the $A n$. angulare Zone contains an admixture of detrital minerals- $(1-\mathrm{m})$ montmorillonite, chlorite, and vermiculite. This zone can be subdivided into a lower part (Section 9-1 to Section 10-4) containing a small but constant admixture of chlorite in the clay fraction, and an upper part (Sections 6-2 and 8-2) containing vermiculite. The Amphirhopalum ypsilon Zone (Sections 1-3 and 5-6), represented by alternating foraminifer-nannofossil oozes and calcareous clays, is characterized by an abundance of unstable Fe-montmorillonite; only in the uppermost part of the section, stable Al-montmorillonite is common. An admixture of detrital minerals (illite, kaolinite, and, less frequently, chlorite) increases somewhat here. Phillipsite occurs in almost every sample.

\section{Hole 419}

This site is located on the southwestern slope of the EPR about 126 kilometers from the spreading axis. The oldest sediments are of Pliocene age, and, on magnetic anomalies, are estimated to be 2.43 to $2.93 \mathrm{~m}$.y. The thickness of the sedimentary cover is 35 meters. The youngest sediments of the Colosphaera tuberosa Zone have not been studied because of lack of samples. Pleistocene sediments of the Anthocyrtidium angulare and Amphirhopalum ypsilon zones, represented by biogenic carbonate-siliceous oozes, have a rather uniform mineralogy in the clay fraction. The latter abounds in Fe-montmorillonite admixed with small amounts of illite. Traces of kaolinite were recognized in one sample only (at the very top of the An. angulare Zone, Section 4-1). 
TABLE 2

Chemical Compositions of K,Fe-Smectites (nontronites)

\begin{tabular}{|c|c|c|c|c|c|c|c|c|c|c|c|c|c|c|c|}
\hline \multirow{4}{*}{$\begin{array}{l}\text { Major } \\
\text { Oxides }\end{array}$} & \multicolumn{7}{|c|}{ K,I e-Smectites from the Galapagos Geothermal Zone } & \multirow{3}{*}{\multicolumn{3}{|c|}{$\begin{array}{c}\text { Fracture Zone "A" } \\
\text { FAMOUS Area } \\
\text { Hydrothermal } \\
\text { Bulk Sediment }\end{array}$}} & \multirow{4}{*}{$\begin{array}{c}\text { Red Sea } \\
\text { (After Butuzova, } \\
\text { et al.,1979) } \\
\text { Fraction }<1 \mu \mathrm{m} \\
\text { Sample 3 St. 1905 }\end{array}$} & \multirow{3}{*}{\multicolumn{4}{|c|}{$\begin{array}{c}\text { K,Fe-Smectite (Celadonite) } \\
\text { Mixed-Layer Minerals from } \\
\text { Santon Caucasus } \\
\text { Fraction }<1 \text { um }\end{array}$}} \\
\hline & \multicolumn{6}{|c|}{ Hole 424B } & \multirow{3}{*}{\begin{tabular}{|c|} 
Site \\
424 \\
Bulk \\
Rock, \\
Hydrother. \\
Oozes
\end{tabular}} & & & & & & & & \\
\hline & \multicolumn{3}{|c|}{ Fraction $<1 \mu \mathrm{m}$} & \multicolumn{3}{|c|}{ Fraction $<10 \mu \mathrm{m}$} & & & & & & & & & \\
\hline & $2-2,90-92$ & $2-3,110-112$ & $3-4,20-22$ & $3-4,20-22$ & $2 \cdot 6,47-49$ & $3 \cdot 2,60-62$ & & $26-15$ & $26-15 A$ & $26-15 B$ & & 356 & 388 & 390 & 2522 \\
\hline $\mathrm{SiO}_{2}$ & 47.98 & 48.19 & 48.09 & 47.20 & 50.47 & 48.20 & 53.81 & 45.59 & 43.11 & 44.39 & 41.70 & 49.67 & 46.67 & 47.73 & 45.58 \\
\hline $\mathrm{TiO}_{2}$ & 0.14 & 0.12 & 0.35 & 0.18 & 0.30 & 0.20 & 0.06 & 0.02 & 0.02 & 0.02 & 0.27 & 0.58 & 0.32 & 0.56 & 1.12 \\
\hline $\mathrm{Al}_{2} \mathrm{O}_{3}$ & 1.44 & 1.80 & 1.48 & 1.92 & 4.90 & 4.28 & 0.36 & 0.2 & 0.21 & 0.21 & 1.90 & 11.28 & 6.96 & 9.04 & 5.54 \\
\hline $\mathrm{Fe}_{2} \mathrm{O}_{3}$ & 30.92 & 30.10 & 27.61 & 28.25 & 24.08 & 24.09 & 26.70 & 38.00 & 34.63 & 37.06 & 35.80 & 16.81 & 22.78 & 18.74 & 24.43 \\
\hline Feō & 0.23 & 0.36 & 1.34 & 0.53 & 0.49 & 0.69 & - & - & - & - & 7.46 & 2.96 & 0.94 & 1.10 & 0.69 \\
\hline $\mathrm{CaO}$ & - & 0.07 & 0.18 & 0.18 & 0.57 & 0.54 & 0.01 & 0.6 & 3.07 & 1.26 & - & 1.92 & 0.56 & 0.41 & 1.30 \\
\hline $\mathrm{MgO}$ & 2.79 & 2.82 & 3.23 & 3.43 & 3.72 & 3.88 & 1.64 & 2.91 & 2.93 & 2.85 & 1.98 & 2.93 & 2.35 & 2.94 & 3.78 \\
\hline $\mathrm{Na}_{2} \mathrm{O}$ & 0.16 & 0.15 & 0.15 & 0.15 & 0.45 & 0.38 & & 3.23 & 3.18 & 2.94 & 0.25 & 1.85 & 1.56 & 1.73 & 1.12 \\
\hline $\mathrm{K}_{2} \mathrm{O}$ & 2.05 & 2.85 & 3.20 & 3.53 & 2.81 & 2.83 & 2.35 & 3.23 & 3.18 & 2.94 & 2.49 & 5.57 & 4.06 & 3.83 & 4.69 \\
\hline $\mathrm{H}_{2} \mathrm{O}^{+}$ & 6.53 & 6.93 & 7.76 & 6.07 & 5.83 & 7.19 & & & & & 5.83 & 4.16 & 5.27 & 2.99 & 6.30 \\
\hline $\mathrm{H}_{2} \mathrm{O}^{-}$ & 7.76 & 6.61 & 6.61 & 8.56 & 6.38 & 7.72 & 15.07 & 6.22 & 9.67 & 8.33 & 2.32 & 2.27 & 8.53 & 10.93 & 5.45 \\
\hline Total & 100.00 & 100.00 & 100.00 & 100.00 & 100.00 & 100.00 & 100.00 & 100.00 & 100.00 & 100.00 & 100.00 & 100.00 & 100.00 & 100.00 & 100.00 \\
\hline
\end{tabular}

Note: $A=$ structural hyers $K$,Fe-illite, $B=$ smeetitic byers. $356,388,390,2522=$ samples of the Geol. Survey, Armenia.

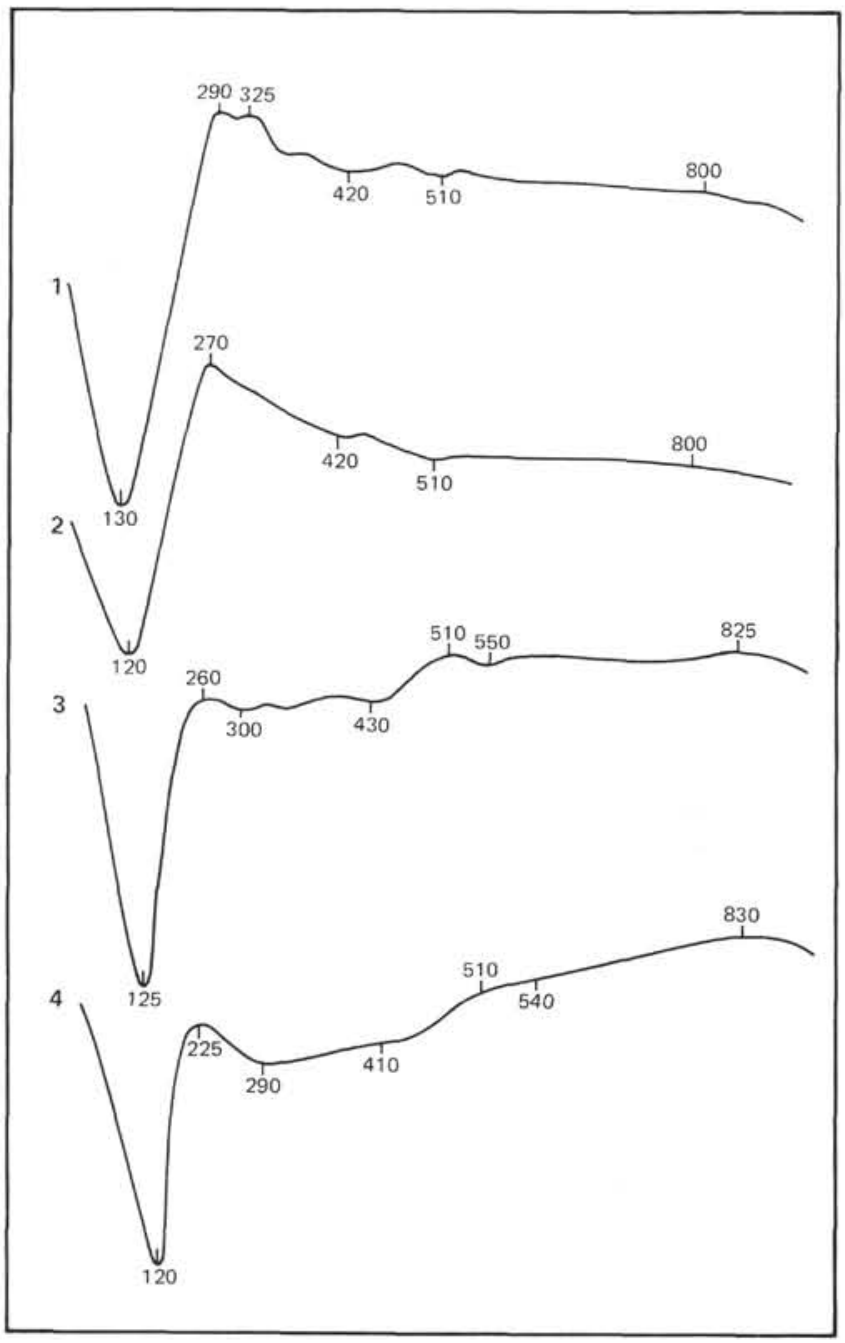

Figure 3. Differential thermograms taken on a derivatograph. Fe-montmorillonites from Hole 420, frac-

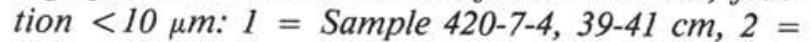
Sample 420-8-4, 59-61 cm; $\mathrm{K}$, Fe-smectite from Hole $424 B$, fraction $<1 \mu \mathrm{m}, 3=$ Sample $424 B-2-3,110$ $112 \mathrm{~cm}$, and $4=$ Sample $424 B-3-4,20-22 \mathrm{~cm}$.

\section{Site $\mathbf{4 2 8}$}

This site is situated south of the latitudinal structure related to the OCP Ridge at 125 kilometers from the axis of the EPR. The thickness of the sedimentary cover penetrated is 61 meters; the age of the basal layer, estimated by means of magnetic anomalies, is 2 to 2.5 m.y.; by radiolarians $1.85 \pm 0.2 \mathrm{~m}$.y., that is, almost the entire Pleistocene, including the thickest Anthocyrtidium angulare and Amphirhopalum ypsilon zones. The sedimentary section of Site 428 is composed of foraminifer-nannofossil oozes, clayey in the lower part, and with rare interbeds of brown calcareous clays in the upper part. In addition, rare thin interbeds of siliceous nannofossil oozes occur. The mineralogy of the clay fraction is uniform; montmorillonite is predominant, and an illitic admixture is small but persistent. Some of the samples contain a negligible quantity of chlorite.

\section{Northern Slope of the EPR}

\section{Hole 422}

This hole is located 5.5 kilometers north of the axis of the latitudinal basin of the OCP Ridge, 109 kilometers west of the EPR. The sedimentary section is 44.6 meters thick and the absolute age of the sediment base is 1.2 to 1.85 m.y.; on the basis of paleomagnetic data, this age is $1.4 \mathrm{~m} . \mathrm{y}$. Basaltic basement was penetrated to a depth of 28.5 meters. The section encompasses the Amphirhopalum ypsilon Zone and is composed of dark-greenish gray foraminifer-nannofossil oozes with an interbed of brown calcareous clay in its upper part. The composition of the clay fraction of these sediments is uniform, being mostly montmorillonite. Illite is present in small quantities as well as chlorite in trace amounts.

\section{Hole 423}

This hole is located 95 kilometers from the axis of the EPR, north of the OCP Ridge. The thickness of the sedimentary cover penetrated is $\mathbf{4 2}$ meters, and the age of the base of the sedimentary pile, based on radiolarians, is 0.5 to $1.2 \mathrm{~m} . \mathrm{y}$. 


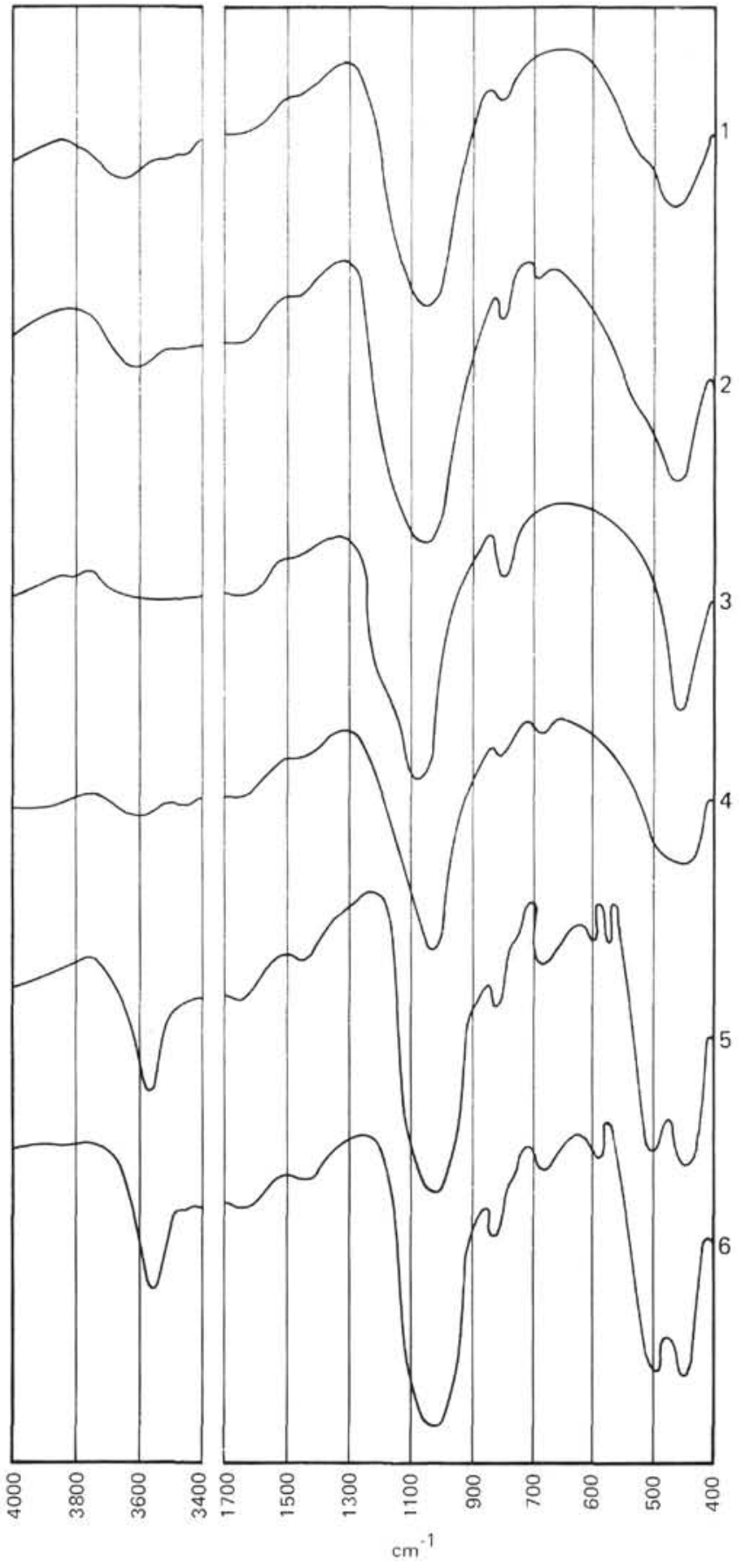

Figure 4. Infrared spectra of Fe-montmorillonites from Hole 420, fraction $<10 \mu \mathrm{m} .1=$ Sample 420-7-4, $39-41 \mathrm{~cm}, 2$ = Sample 420-8-4, 59-61 cm, 3 = Sample 420-9-1-59-61 cm, 4 = Sample 420-12-3, 60-62 $\mathrm{cm} ; \mathrm{K}$, Fe-montmorillonites from Hole $424 B$, fraction $<1 \mu \mathrm{m}, 5=$ Sample $424 B-2-3,110-112 \mathrm{~cm}, 6=$ Sample 424B-3-4, 20-22 cm.

The stratigraphic interval (Section 3-2 to Section 5-4) of the Amphirhopalum ypsilon Zone, characterized by alternating foraminifer-nannofossil oozes and nannofossil oozes, contains mostly montmorillonite in the clay fraction. Illite is present as well as traces of

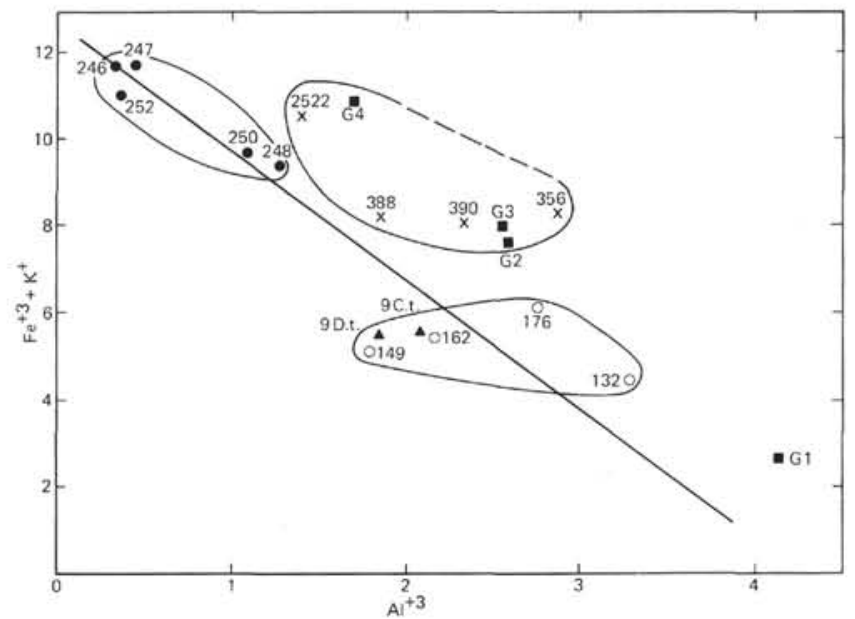

Figure 5. Classification of smectites on the basis of the modulus $(\mathrm{Fe}+\mathrm{K}) / \mathrm{Al} . \mathrm{O}=\mathrm{Fe}$-montmorillonites from the EPR region of Hole 420. 132 = Sample 420-4-3, $59-61 \mathrm{~cm}, 149=$ Sample 420-8-2, 59-61 cm, $162=$ Sample 420-10-5, 60-62 cm, 176 = Sample 420-13-5, $56-61 \mathrm{~cm} . \bullet=K, \mathrm{Fe}$-smectites from Hole 424B of the Galapagos geothermal field. $246=$ Sample $424 B$ 2-2, 90-92 cm, $247=$ Sample 424B-2-3, 110-112 $\mathrm{cm}, 248=$ Sample $424 B-2-6,47-49 \mathrm{~cm}, 250=$ Sample 424B-3-2, 60-62 cm, 252 = Sample 424B-3-4, $20-22 \mathrm{~cm} ; \boldsymbol{\Delta}=\mathrm{Fe}$-montmorillonites Samples $9 \mathrm{Ct}$ and $9 \mathrm{Dt}$ from Japanese investigators of the EPR (Aoki et al., 1974); $\mathrm{x}=$ hydrothermal celadonite celadonite-smectites from the Lesser Caucasus Santonian (Rateev et al., 1974); $\mathbf{\square}=$ glauconites after Winchell (1951); $G_{1}=$ deep-sea glauconite, $G_{2}$ and $G_{3}=$ glauconites, less-deep sea, $G_{4}=$ glauconite from sandstones of the shelf.

kaolinite. The overlying foraminifer-nannofossil oozes of the Colosphaera tuberosa Zone have the same association of clay minerals. A vermiculitic mineral (admixed with minor montmorillonite) predominates in brown calcareous clays in the uppermost part of the $C$. tuberosa Zone.

\section{Galapagos Spreading Center Regions}

\section{Holes 424 and 424B}

Holes 424 and 424A, B, and C are situated approximately 0.2 to 0.4 kilometers from the meridional section of the geothermal field, 22 kilometers south of the GSC. On the basis of magnetic data, the age of the basal layer of sediment of Hole 424B is 0.4 to 1.2 m.y. The age of the youngest sediments is 200,000 to $400,000 \mathrm{y}$., but oxidized sediments penetrated in the uppermost part of the section in Hole 424B are Recent ooze.

The so-called green hydrothermal oozes are the most interesting sediment of Hole 424B; they alternate with foraminifer-nannofossil oozes, up to 20 meters thick, involving the Amphirhopalum ypsilon Zone. X-ray diffraction analysis shows that they are not of smectitechlorite composition but rather $\mathrm{K}, \mathrm{Fe}$-smectite, similar to nontronite. This mineral appears to be present in two 


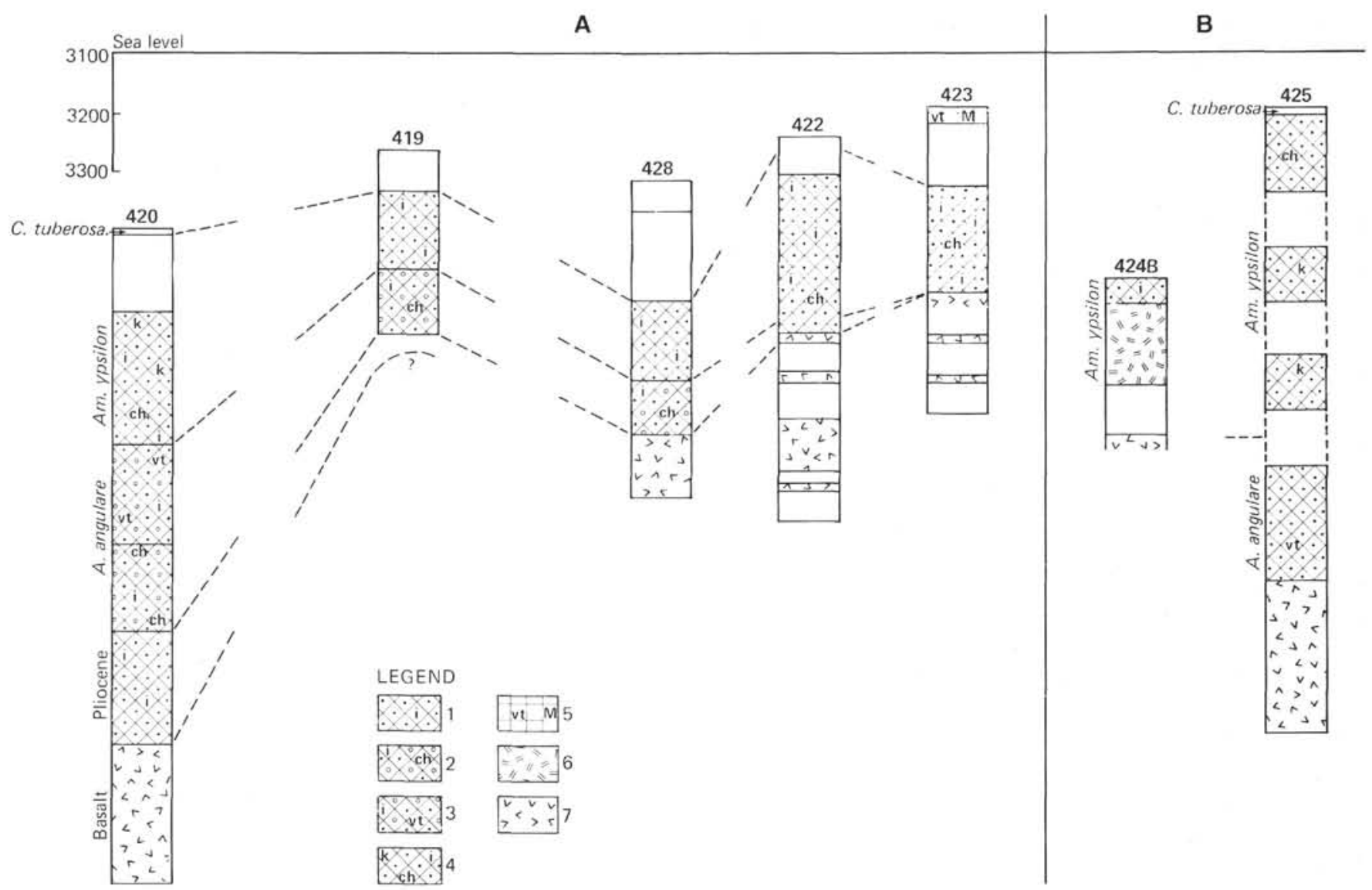

Figure 6. Distribution scheme for clay minerals in the area of Leg 54. $A=E P R$ region and OCP Ridge, $B=$ Galapagos geothermal field. Symbols for Figures 6 and 7: $1=$ Fe-montmorillonite (authigenic with an illite admixture, 2 = two types of smectites - authigenic ferruginous, and detrital with illite and a negligible admixture of chlorite, $3=$ two types of smectites with an admixture of vermiculite-like mineral; $4=\mathrm{Fe}$-montmorillonite, with admixture of illite, kaolinite, and, less frequently, chlorite; 5 = vermiculitic mineral with a smectitic admixture; 6 $=K, \mathrm{Fe}$-smectite of green hydrothermal oozes; $7=$ basalts. $i=$ illite, ch $=$ chlorite, $K=$ kaolinite, $v t=$ vermiculite-like mineral, and $M=$ montmorillonite.

generations, pale green and a darker, bright grassy green. $\mathrm{K}$, Fe-smectite forms authigenic patches replacing ellipsoidal organic remains leading to the formation of pseudomorphs. Birefringence of the $\mathrm{K}, \mathrm{Fe}$-smectite is second-order bluish grey; appreciable aggregate polarization is usually representative of smectites rather than chlorites. This agrees well with the $\mathrm{K}, \mathrm{Fe}$-smectitic structure of the mineral.

$\mathrm{K}, \mathrm{Fe}$-smectites are accompanied by rare elongated plates of brown, relatively fresh biotite, authigenic hydrobiotite, and small opal globules.

The hydrothermal K, Fe-smectite oozes are overlain by nannofossil-foraminifer oozes of the Colosphaera tuberosa Zone, the clay fraction of which is characterized by an entirely different composition. It abounds in common montmorillonites rather than $\mathrm{K}$, Fe-smectites, with the basal peak $d / 001=14.7 \AA$ (air-dry specimens).

\section{Hole 425}

This hole, the most remote from the GSC $(62 \mathrm{~km})$, is located in the topographic low with a higher heat flow. Here the oldest sediments are of early Pleistocene age, judged by magnetic data to be $1.8 \mathrm{~m}$.y. old. The total thickness of the sedimentary cover penetrated is 79 meters.

The clay fraction of the oldest part of the section, the Anthocyrtidium angulare Zone, composed of alternating foraminifer-nannofossil oozes and siliceous oozes, contains montmorillonite with, in places, an admixture of illite-vermiculite. In the upper part of the section, the Amphirhopalum ypsilon Zone, the same type of sediments with a similar type of clay fraction, contains small admixtures of kaolinite and chlorite, besides montmorillonite.

Thus, at a distance from the Galapagos geothermal field (Site 424), the synchronous sediments of the $\mathrm{Am}$. ypsilon Zone of Hole 425 are composed of common montmorillonite with a small admixture of detrital minerals rather than $\mathrm{K}, \mathrm{Fe}$-smectite.

\section{GENETIC RELATIONSHIPS OF CLAY MINERALS DURING SEDIMENTATION AND DIAGENESIS}

A clay mineral association of Pliocene-Pleistocene deposits of the OCP Ridge situated on the western slope of the EPR is surprisingly uniform. The clay fraction is 
composed mostly of unstable authigenic Fe-montmorillonite making up from 50 to 95 per cent of the total clay minerals, frequently with zeolite of the phillipsite type, and with hematite and manganese compounds. It is usually accompanied by such detrital minerals as illite $(20-35 \%)$, kaolinite $(10-20 \%)$, and, much less frequently, chlorite $(<5 \%)$. Fe-montmorillonite, the main component of the clay fraction, was recognized at all of the Leg 54 sites except Hole 424B (Galapagos geothermal field), where iron-rich $\mathrm{K}, \mathrm{Fe}$-smectites (with up to $31 \%$ $\mathrm{Fe}_{2} \mathrm{O}_{3}$ ) were recovered.

$\mathrm{Fe}$-montmorillonite from Hole 420 is characterized by $\mathrm{Fe}_{2} \mathrm{O}_{3}(10-14 \%), \mathrm{Al}_{2} \mathrm{O}_{3}(6.9-12.9 \%)$, and $\mathrm{K}_{2} \mathrm{O}$ $(1.1 .-2.2 \%)$ contents, and extreme instability when treated with $\mathrm{HCl}$. It is similar to the iron-rich smectite described by Aoki et al. (1974).

Microscopic studies show that it is a product of devitrification of basaltic volcanic glass. The mineral forms nodules or globules, frequently around vitroclastic fragments that are coated on the periphery by earthy manganese compounds. The process of nodule formation is especially pronounced in upper Pliocene sediments of Hole 420. The mineral is authigenic as it frequently fills cavities in radiolarian skeletons, or replaces coprolites. Fe-montmorillonite is apparently produced as the dissolved forms of silicate elements $\mathrm{Fe}, \mathrm{Al}$, $\mathrm{K}, \mathrm{Mg}$, and $\mathrm{Si}$ accumulate during early diagenesis. This occurs as a result of a long process of devitrification of unstable, basic vitroclastic material or biotitic micas of the trioctahedral series. During this process, nodules do not acquire extra hardness; following redeposition, they become fragmented, frequently imparting a brecciated structure to the sediments. Fe-montmorillonites are derived from basic pyroclastic material rather than silicic ash, because basic rocks are much more readily affected by montmorillonitization than acidic ones (Timofeev, et al, 1979). Furthermore, acid ash layers from terrestrial volcanoes usually occur with definite periodicity. In deep sea Pliocene-Quaternary sediments of the equatorial Pacific, Bowles et al. (1973) singled out the two most extensive ashfall maxima (by volume $43 \mathrm{~km}^{3}$ and $19 \mathrm{~km}^{3}$ ); they are dated isotopically to be 220,000 and $54,000 \mathrm{y}$. old, respectively. These authors consider the Guatemala Upland (Salvador, Columbia, Ecuador, or Nicaragua) to be the most probable source areas of this ash supply.

In contrast to such concentration of ash material, the authigenic Fe-montmorillonite, as already emphasized, is distributed most uniformly throughout the section of Pliocene-Quaternary sediments in all Sites of Leg 54, as it is related to underwater basaltic volcanism.

In the region of the GSC, near the geothermal field in Hole 424B, K,Fe-smectite of hydrothermal origin was identified. This green mineral is characterized by a higher content of $\mathrm{Fe}_{2} \mathrm{O}_{3}(27.6-30.9 \%)$ in the fraction $<1 \mu \mathrm{m}$, a very low percentage of $\mathrm{Al}_{2} \mathrm{O}_{3}(1.1-1.8 \%)$, and somewhat higher $\mathrm{K}_{2} \mathrm{O}$ content $(2.1-3.9 \%)$. In the area of Hole 424B during Pliocene-Quaternary time, the sedimentary section produced consists of nannofossil-foraminiferal oozes containing 74 to 80 per cent $\mathrm{CaCO}_{3}$. Other constituents are clay minerals, biogenic silica and, in some interbeds, colorless fragments of acidic volcanic glass.

We believe that the hydrothermal clay minerals of Site 424 were formed by reactions between underlying basalts and circulating, highly mineralized hydrothermal brines enriched in potassium. This conclusion is based on the data reported here and our own observations in the field. The clay minerals appear to have formed by reaction between hydrothermal brines fluxing from basement, and sediment interstitial waters, or sea water. However, such a process of hydrothermal authigenic clay formation could have proceeded only where the rate of precipitation of clay minerals from dissolved ferruginous-siliceous components greatly exceeded or suppressed the biogenic sedimentation rate. Quite often in these types of deposits we find manganiferous precipitates formed simultaneously with green, potash-bearing, iron-rich smectite. These frequently contain fragments of altered vitroclastic material in nucleii which are coated with bright green $\mathrm{K}, \mathrm{Fe}$-montmorillonite and have inclusions of clustered aggregates of $\mathrm{Fe}-\mathrm{Mn}$ hydroxides and the finest of opal spherulites. The green $\mathrm{K}, \mathrm{Fe}$-smectite in these nodules is also accompanied by a small amount of authigenic sulfide (pyrrhotite or pentlandite), testifying to slightly reducing conditions during its formation.

The formation of authigenic Fe-montmorillonite in the marine environment as we envision it is thus assisted by low rates of sedimentation, an oxidizing medium, and the presence of metastable components (basic vitroclastic materials, biotitic trioctahedral micas, biogenic silica, etc.). The slow process of decomposition of metastable, finely dispersed silicate material yields high concentrations of silicate-forming elements, $\mathrm{Fe}^{+3}, \mathrm{Fe}^{+2}$, $\mathrm{Al}^{+3}, \mathrm{Mg}^{+2}$, and monomeric $\mathrm{Si}^{+4}$, which can synthesize new forms of layered silicates and, most importantly, Fe-montmorillonite. The latter, we believe, is transformed diagenetically into mixed-layer, celadonitesmectite, or glauconite-smectite authigenic minerals. The processes of celadonitization or glauconitization in oceanic diagenesis proceed through the same crystallochemical transitions as during the formation of the initial form of authigenic Fe-montmorillonite, which has an $\mathrm{Fe}_{2} \mathrm{O}_{3}$ content of 14 to 18 per cent. This process consists in progressive replacement of $\mathrm{Al}^{+3}$ by $\mathrm{Fe}^{+3}$ and partly $\mathrm{Fe}^{+2}$ in the octahedral layer of smectitic lattice. Potash cations enter interlayer spaces of smectites, thus promoting formation of celadonite-smectite or glauconite-smectite mixed-layer minerals. It seems to us that the process of ferruginous montmorillonitization, rather widely developed in oceanic sediments (especially in the oxidizing zone of the Pacific Ocean), is an initial stage of celadonitization (with endogenic inflow) or glauconitization. It is caused by diagenetic mobilization of soluble forms of silicate-forming elements. Depending on endogenic and exogenic factors of sedimentation and mineral formation, it proceeds according to the scheme shown in Figure 7, and is dependent on a number of important factors:

1) structural similarity of $\mathrm{Fe}$ - and $\mathrm{K}, \mathrm{Fe}$-montmorillonite to the smectite crystal lattice; 


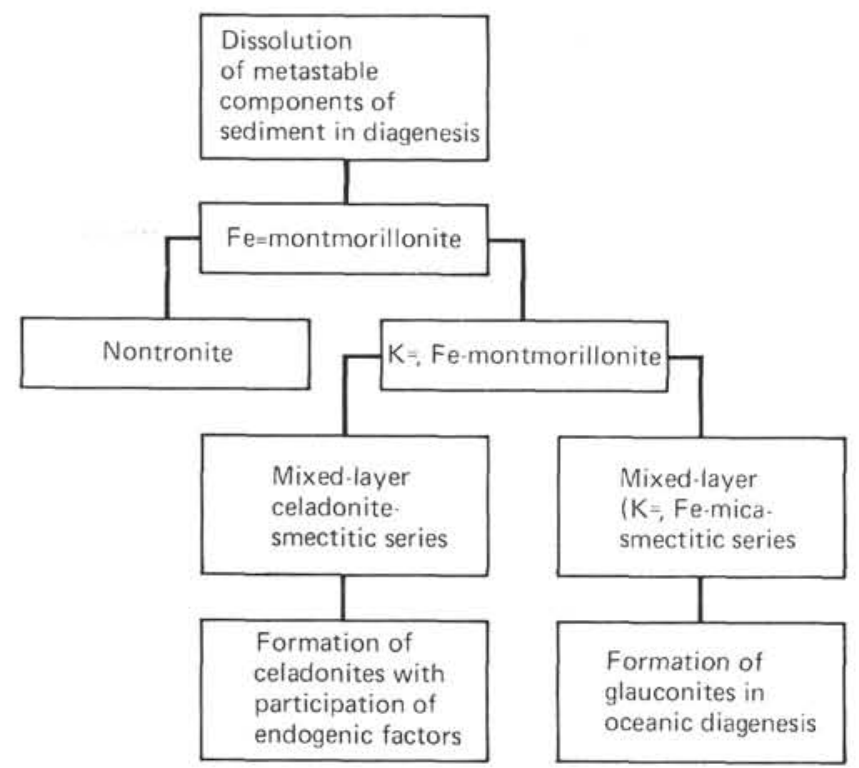

Figure 7. Scheme for authigenic clay formation in early diagenesis.

2) the presence of a plausible crystallochemical mechanism of transformation of Fe-montmorillonite into $\mathrm{K}, \mathrm{Fe}$-smectite at first by means of replacement of $\mathrm{Al}^{+3}$ by $\mathrm{Fe}^{+3}$ in the octahedral layer, and subsequently through mixed-layer phases with fixation of $\mathrm{K}$ cations in the $\mathrm{K}, \mathrm{Fe}$-smectitic lattice;

3 ) the presence of transitional mixed-layer celadonite-smectitic structures between $\mathrm{Fe}$ - and $\mathrm{K}, \mathrm{Fe}$-montmorillonites (Figure 5, Tables 1 and 2), which fill an important compositional gap between these minerals (Rateev et al., 1974);

4) discovery of numerous examples of clays with mixed-layer structure (the "potash ferruginous micasmectites") among recent and young glauconites not altered by epigenesis (Rateev et al., 1978; Lisitzina et al., 1974);

5) abundance of fresh glauconites with partially expanded lattices, relics of the former smectite structure;

6) considerable compositional variation among glauconites and resemblance of many of them to $\mathrm{Fe}-$, and $\mathrm{K}, \mathrm{Fe}$-montmorillonites described by us.

The process of structural transformation of Fe-montmorillonite into celadonite-smectitic minerals has recently been well described by Butuzova et al. (1979) for sediments from the depression Atlantis II of the Red Sea, deposited in the zone of intense inflow of thermal brines. The authors identified Fe-montmorillonite of the nontronite type in the upper oxidizing zone. This $\mathrm{Fe}$-smectite resembles strongly Fe-montmorillonite described by Bischoff (1972). According to this author's data, the Fesmectite in the zone of ore-bearing sediments of the Red Sea is formed by interaction of hot brines, containing about 60 parts per trillion (ppt) of $\mathrm{SiO}_{2}$ and $80 \mathrm{ppt} \mathrm{Fe}{ }^{+2}$, with bottom sea water. Cooling of the brines as a result of mixing with sea water led to oversaturation with $\mathrm{Si}^{+4}$ ions. The greater part of iron was then oxidized, and synthesized smectite settles into a sediment together with an amorphous jelly mass consisting mostly of a mixture of
$\mathrm{SiO}_{2}$ with $\mathrm{Fe}$ hydroxides. Butuzova et al. (1979) showed that as these sediments become more deeply buried, accumulation and fixation of potassium in interlayers of dioctahedral $\mathrm{Fe}$-montmorillonite takes place. As a result, they become partly micaceous and cannot expand when saturated with organic liquids. Accordingly, $d / 001$ peaks of heated samples vary regularly from $9.54 \AA$ in surface layers to $9.83-9.86 \AA$ in deeper horizons of the geological column.

It should be emphasized that in saturation of Fe-montmorillonite samples from the lower horizons with $\mathrm{K}_{2} \mathrm{CO}_{3}$, their diffractograms resemble those of glauconite or celadonite. We believe that these facts bespeak the possibility of an initial authigenic synthesis of Fe-montmorillonite, followed by structural transformation of the latter into celadonite or glauconite through an intermediate mixed-layer stage. This is confirmed by the following: "...these layers having similar orientation and similar rates of preferred growth are, by nature of interlayer spaces, smectites; because their structure consists of alternating octahedral and tetrahedral layers, they already potentially contain everything necessary for subsequent transformation to a three-dimensionally ordered micaceous phase of the polytype modification IM. In this transformation, all that need be done is simply an introduction of large $\mathrm{K}$ cations into interlayer sites, and their fixation." (Butuzova et al., 1979).

These authors also explain the orientation of fibrous, elongate, platy, or lath-shaped particles of Fe-montmorillonite and celadonite $\mathrm{K}, \mathrm{Fe}$-smectites. The lathshaped crystals occur, they argue, because of differential growth rates of octahedral and tetrahedral (2:1) layers, particularly in various crystallographic directions. According to experimental data, the maximum rates of growth are greatest on the "a" axis; that is, in the plane of symmetry of layers. We believe this also explains the elongate, platy habit of the particles of $\mathrm{Fe}$ - and $\mathrm{K}, \mathrm{Fe}-$ montmorillonite from Leg 54 holes (Figure 8).

\section{REMARKS ON THE DISTRIBUTION OF DETRITAL CLAY MINERALS IN THE PANAMA BASIN}

It is useful to analyze concentrations of detrital, terrigenous clay minerals in different basins (e.g., Rateev, 1964). We assume that during the Pleistocene in the eastern equatorial Pacific Ocean, both sedimentation and clay formation were essentially the same as now, and in Recent time. We can, consequently, reconstruct the sedimentation history of the Panama Basin by using the quantitative data of Heath et al. (1974). These investigators propounded schemes for the distribution of smectite, illite, kaolinite, and chlorite in the surface sediments of the Panama Basin (Figure 9). Two genetic types of smectite were distinguished: authigenic/diagenetic (essentially volcanogenic) related to areas of active underwater volcanism, and detrital (i.e., terrigenous supplied from continents). The highest concentrations of authigenic smectite are associated with basement of the GSC and the region west of it (the Galapagos Islands), to the eastern termination of Carnegie Ridge, and to the northern margin of Cocos Ridge (Kowsmann, 1973), that is, to all regions most enriched 


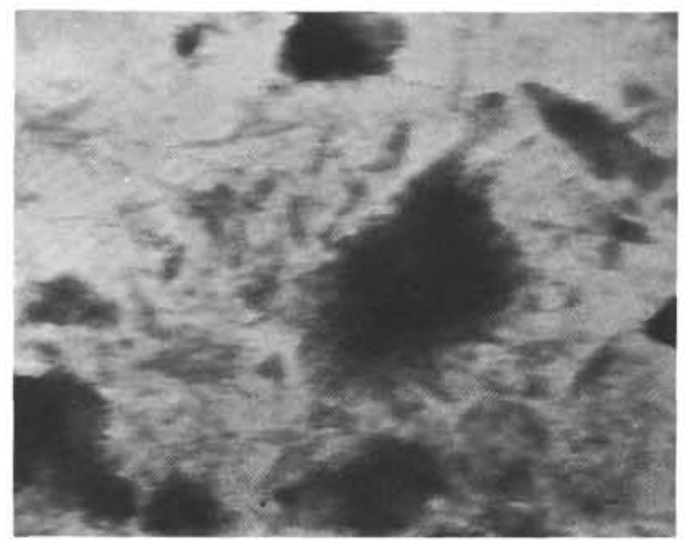

a

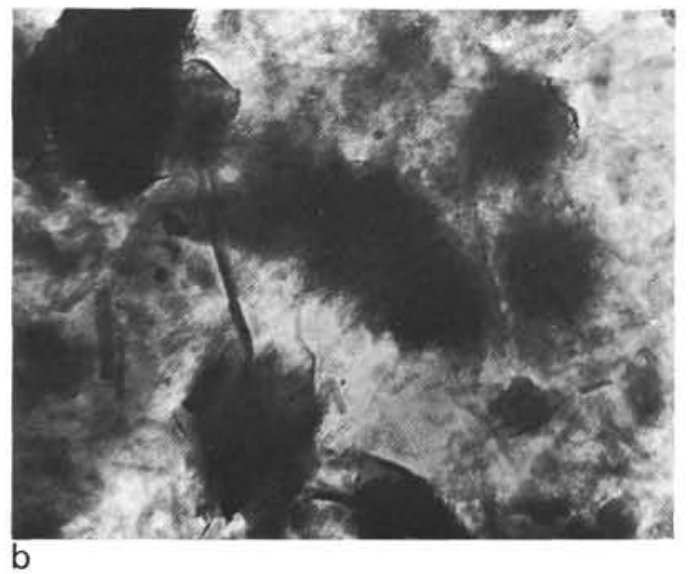

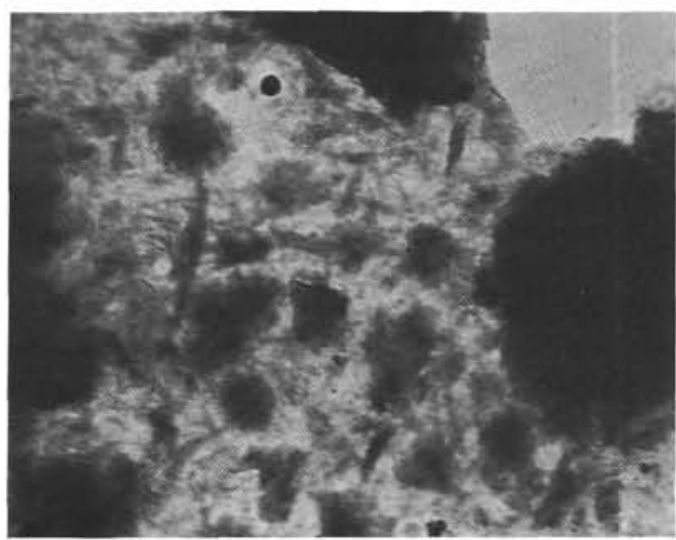

C

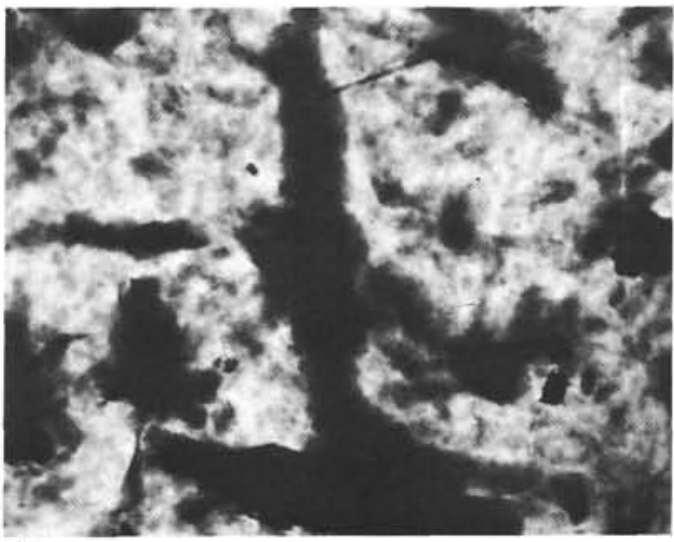

$\mathrm{d}$

Figure 8. Electron-microscopic photographs: $K, F e$-smectites from green oozes from the Galapagos geothermal field. Hole 424B: $a=$ Sample 2-2, 90-92 cm; b, $c=$ Sample 3-2, 60-62 cm, Fe-montmorillonite from Hole 420 (EPR); $d=$ Sample 13-5, $56-61 \mathrm{~cm}$.

in fragments of either subaerial volcanogenic pyroclastic or submarine vitroclastic material. A similar enrichment in authigenic smectite occurs in sediments on Coiba Ridge and to transform faults near $85^{\circ} \mathrm{W}$ (Heath et al., 1974).

The summarized scheme for concentration of authigenic smectite in the Panama Basin (Heath et al., 1974) shows considerable impoverishment in the northeastern part of the Basin, and an increase toward the southwest (i.e., deeper) parts of the Basin.

Illite in the Panama Gulf sediments does not exceed 20 per cent in the $<2=\mu \mathrm{m}$ fraction. The highest concentrations of illite $(15-20 \%)$ occur on the continental slope from North Ecuador to the southern part of Panama. The formation of the zone of maximum illite concentrations $(15-20 \%)$ is related to current drifts of the Esmeraldas, Mira, and Patia rivers, the suspensions of which are characterized by the highest illite concentrations. Toward the southwest, maximum illite concentrations are reduced first to 10 to 15 per cent and then 5 to 10 per cent; the northwestern part of the Panama Basin is poor in illite $(2-5 \%)$. The configurations are not controlled by bathymetry. Transportation of a part of illite, as Heath et al. (1974) believe, is carried out by means of so-called intermediate currents (at depths from 300 to
$2000 \mathrm{~m}$ ), where the concentrations of suspensions in the water column are the highest.

Detrital kaolinite in the uppermost Recent sediments of the Panama Basin ranges over the greater part of the area in concentrations from 10 to 20 per cent and sometimes even higher. The distribution of kaolinite particles is similar to that of illitic particles, but is more regular and more closely associated with the source of supply. Differences may be related to a somewhat different size of particles and their deposition rates or coagulation point (Whitehouse et al., 1958). A larger quantity of kaolinite is supplied to the area (in the northeastern part of the basin) from the San Juan and Esmeraldas rivers, but the extensive zones of a relatively higher kaolinite content $(>20 \%$ and $15-20 \%)$ in the northeastern part of the Panama Basin make us think that the supply of kaolinite into oceanic deposits may as well be from areas of low topography with intense chemical weathering.

Chlorite can be supplied to oceanic sediments if the intensity of erosion exceeds the rate of chemical weathering. Such conditions are at present known to prevail in Western Columbia. Heath et al. (1974) consider this area the main source for Panama Basin sediments. The authors believe that basic and ultrabasic, partly meta- 

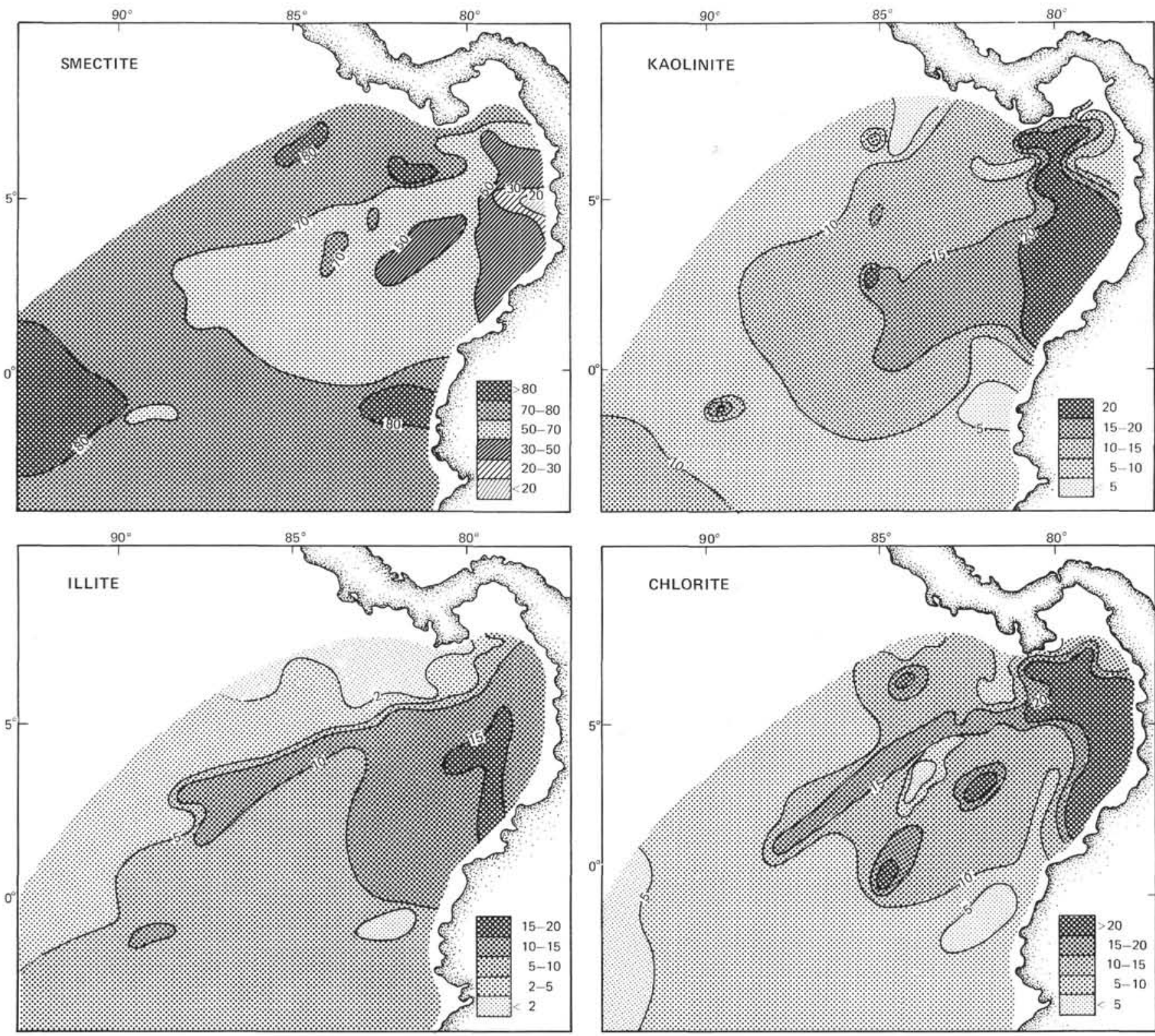

Figure 9. Schemes for the quantitative distribution of clay minerals in surface of the Panama Basin sediments, after Heath et al. (1974).

morphosed rocks drained by the San Juan river, are likely to supply the major part of chlorite. Isolated patches of higher chlorite concentrations in the western part of the Cocos Ridge are due to rewashing of more chloritic enriched Pleistocene sediments, rather than Holocene ones. The sediments enriched in volcanogenic material, such as in the eastern termination of the Carnegie Ridge and to the west of the Galapagos archipelago, are usually poor in chlorite. Therefore, we, as well as Heath et al. (1974) consider chlorite, illite, and kaolinite in all the studied Pliocene-Quaternary sediments to be detrital. As to the mechanism of their redistribution, we do not consider particle size to be the most important factor. Most probably, the quantity of one or another mineral depends much more on the distance from the source area and, to a lesser degree, on separation by submarine topography and transportation by bottom currents.

\section{REFERENCES}

Aoki, S., Kohyama, N., and Sudo, T., 1974. An iron-rich montmorillonite in sediment core from northeastern Pacific. Deep-Sea Res., v. 21 (10), p. 865-877.

Biscaye, P. E., 1964. Mineralogy and sedimentation of the deep-sea sediment fine fraction in the Atlantic Ocean and adjacent seas and oceans. Geochemistry Technical Report 8, Yale University, p. 1-86.

Bischoff, J. L., 1972. A ferronontronite from the Red Sea geothermal system. Clays and Clay Minerals, Proc. Internat. Clay Conference, Madrid, 1972, v. 20, p.217-223. 
1974. Sediments of geothermal brines Red Sea. In Hot Brines and Recent Heavy Metal Deposits in the Red Sea: Berlin-Heidelberg-New York (Springer), p. 157-194.

Bowles, T. A., Jack, R. N., and Carmichael, I. S. E., 1973. Investigation of deep-sea volcanic ash layers from Equatorial Pacific cores. Geol. Soc. Am. Bull., v. 84 (7), p. 237239.

Brindley, G. W., 1951. X-ray Identification and Crystal Structures of Clay Minerals: London (Mineralogical Society).

Butuzova, G. Yu., Drits V. A., Lisitzina N. A., Tsipursky, N. A., and Dmitrik, A. L., 1979. Dynamic formation of clay minerals in ore-bearing sediments through Atlantis II Red Sea. Lithol. and Miner. Resources, v. 6, p. 3-20.

Butuzova, G. Yu., Lisitzina, N. A., and Gradusov, B. P., 1977. Clay minerals in sediments on the profile through the Pacific Ocean. Ibid., v. 4, p. 3-18.

Drits, V. A., and Sakharov, B. A., 1976. X-ray structural analysis of mixed-layer minerals. Trans. Geol. Inst. AN USSR, v. 295 , p. $1-256$.

Gradusov, B. P., 1976. Minerals with Mixed-Layer Structure in Soils: Moscow (Nauka), p. 1-127.

Green-Kelly, R., 1953. The identification of montmorillonoids in clays. J. Soil Sci., v. 4 (2), p. 233-237.

Hashimoto, H., and Jackson, M. L., 1960. Rapid dissolution of allophane and kaolinite-halloysite after dehydration. Clay Minerals, v. 5, p. 21-25.

Heath, G. R., Moore, T. C., and Roberts, G. L., 1974. Mineralogy of surface sediments from the Panama basin, eastern equatorial Pacific. J. Geol., v. 82 (2), p. 145-161.

Kossovskaya, A.G., Guschina, E. B., Drits, V. A., Dmitrik, A. L., Lomova, O. S., and Serebrehnikova, N. D., 1975. Mineralogy and genesis of Meso-Cenozoic deposits in the Atlantic Ocean according to the data of Glomar Challenger voyage 2. Lithol. and Miner. Resources, v. 6, p. 12-36.
Kowsmann, R. O., 1973. Coarse components in surface sediments of the Panama Basin Eastern equatorial Pacific. $J$. Geol., v. 81 (4), p. 473-495.

Lisitzina, N. A., Gradusov, B. P., and Tshishikova N. P., 1977. Glauconite as diagenetic formation of reduction zone of the oceanic sediments. Lithol. and Miner. Resources, v. 6 , p. $3-20$.

MacEwan, D. M., 1955. Fourier transform methods for studying scattering from lamellar system. Kolloid. Zeitschrift, v. 149 , p. $96-108$.

Rateev, M. A., 1964. Regularities in the distribution and genesis of clay minerals in recent and old marine basins. Trans. Geol. Inst. AN USSR, v. 112, p. 5-241.

Rateev, M. A., Gradusov, B. P., and Iljnskaya, M. N., 1974. Genesis of bentonitic clay. Dasch-Salachly (Kaukasus), Bull. MOIP (Section Geol.), v. 69(5), p. 72-89.

Reynolds, R. G., 1968. The effect of particle size on apparent lattice spacing. Acta Crystall., v. A 24, p. 5-6.

Timofeev, P. P., Rateev, M. A., and Rengarten, N. V., 1979. Mineralogy of the clay fraction of the Atlantic Ocean sediments, DSDP Leg 48. In Roberts, D. G., Montadert, L., et al., Initial Reports of the Deep Sea Drilling Project, v. 48: Washington (U. S. Government Printing Office), p. 10911098.

Whitehouse, U. G., Jeffry, L. M., and Debrecht, J. D., 1958. Differential settling tendencies of clay minerals in saline water. Proc. 7th Nat. Conf. Clays and Clay Minerals: London.

Winchell, A. M., 1951. Elements of Optical Mineralogy: New York (Elsevier), p. 359-360.

Zolotarev, B. P., and Frolova, T. I., 1978. Petrochemistry of recent oceanic basalts. Proceedings Oceanographic Conference: Moscow (Nauka), p. 21-23. 